\title{
TEXTURE VERSUS DISTANCE OF TRAVEL OF GRAVELS ON A STREAM BED: A CASE STUDY FROM FOUR STREAMS IN NW PELOPONNESE, GREECE
}

\author{
Kourkounis S. ${ }^{1}$, Panagiotakopoulou O. ${ }^{1}$, Zelilidis A. ${ }^{1}$, and Kontopoulos N. ${ }^{1}$ \\ ${ }^{1}$ University of Patras, Department of Geology, Laboratory of Structural Geology, 26500 Patras, Greece, \\ a.zelilidis@upatras.gr,kontopou@upatras.gr
}

\begin{abstract}
This study concerns the change of lithology, grain size and roundness of gravels with distance downstream in lowland area from four streams which are Krathis, Kerinitis, Meganitis and Finikas. Four types of gravelly clast lithology were collected: limestone, chert, sandstone and conglomerate. In Krathis stream, the absence of variability in lithologic content is due to a short travel. The variability of the arithmetic mean depends on the width of stream channel. The roundness either remains constant or becomes better downstream because of selective transport. In Kerinitis stream, the variability or the invariability in the lithologic content is due to partly or local sample variation, partly to influx of new material, and partly to effects of increase or decrease of other types. The arithmetic mean and roundness either remain constant or are decreased downstream due to the contamination and the short travel. In Meganitis Stream, the lithologic content shows variability, the arithmetic mean absence of downstream fining gravel and the roundness variability or invariability because of the contamination and gravel mining. In Finikas Stream, the lithological content, the arithmetic mean and the roundness show either variability or invariability because of the gravel mining.
\end{abstract}

Key word: Lithology, grain size, roundness, gravels, streams, NW Peloponnese.

\section{Introduction}

It has long been established that parameters such as particle size, shape and roundness change progressively downstream in coarse grain alluvial deposits as a consequence of the sorting, mechanical abrasion and chemical weathering in sediment transport. Previous investigators have attributed downstream fining to both selective sorting and abrasion. Downstream trends in fining can be interrupted or overridden by lateral inputs of coarse sediments from tributary channels and hillslope processes. The downstream changes in the lithology of stream gravels depend on the resistances of various rock types to abrasion and breakage. Krumbein (1942) and Plumley (1948) concluded that the roundness increases as a logarithmic function of distance. Moreover, the rounding does increase with distance, most rapidly at first and then more slowly (Pettijohn, 1973). There seems to be a limiting roundness, in part related to the lithology of the materials- lower, for example, for chert than for quartz or limestone. Previous studies of changes in fluvial size distribution and roundness in a downstream direction are completely limited in Greece (Kontopoulos \& Panagos, 1979; Karkanas \& Kontopoulos, 2004).

The aim of this work is to test and reason the downstream change of size and roundness in braided stream gravels in northwestern Peloponnese. 


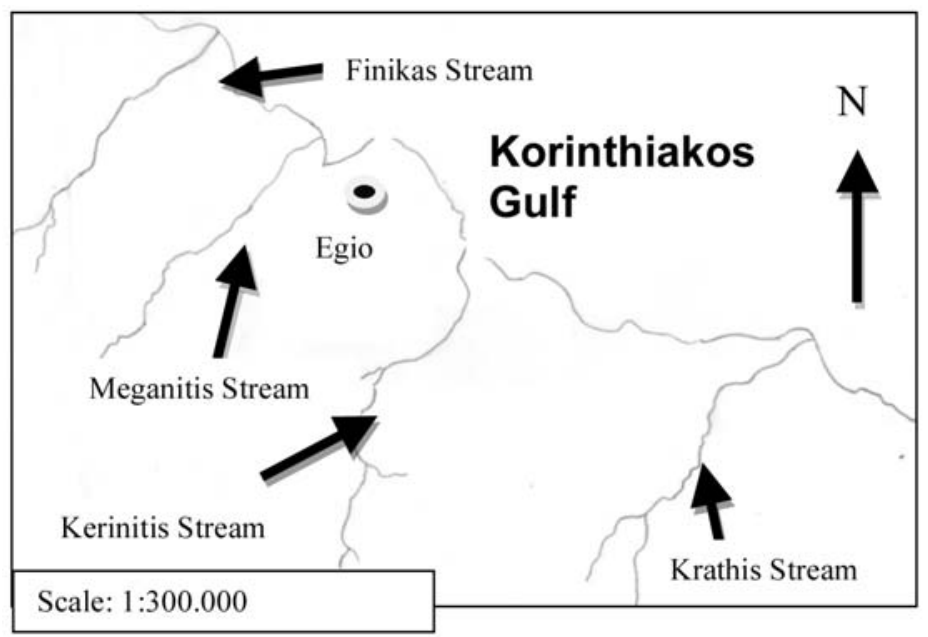

Fig. 1: Simplified sketch which shows the streambeds of study streams.

\section{Study area}

Four sampling areas were chosen (Fig. 1). These are the streambeds of Krathis, Kerinitis, Meganitis, and Finikas streams. These are the main channels of fan deltas which were established on southwest coast of Korinthiakos Gulf. The mean value of Kerinitis streambed steepness is about 1.9 degree in its distal part while in the other three streams is about 2 degree. The stream source areas consist of limestone and flysh of Pindos zone and Pliocene and Pleistocene fine-grained sediments while the bedrock of Tripolis zone is one additional source area for Krathis stream.

\section{Methods}

Sample sites were chosen in order to give an overview of the downstream clast changes (Figs. 2, 3, $4,5)$. Field sampling of clasts was made following Bunt and Abt (2001) using sampling frame and a tape measure stretched from bank to bank. Each clast was identified to rock type and the following parameters were measured: (1) b axis and (2) roundness after Krumbein (1942).The statistical validity of the downstream changes in arithmetic mean (b) and roundness were tested using multiple comparisons in one-way analysis of variance and Dunkan'test at a $0.1 \%$ significance level. Levene's test for the homogeneity of variances was used. The statistical validity of the downstream changes in lithology was tested using $\mathrm{X}^{2}$ method. The studied relative resistances to abrasion and breakage of the rock types were calculated on basis of the chert ratio.

\section{Results}

\subsection{Krathis Stream}

The percentage of all lithologies shows insignificant changes downstream (Table 1, Fig. 6).

The arithmetic mean of limestone pebbles decreases significantly from sample site 2 to sample site 4 while the arithmetic mean of sandstone and conglomerate pebbles shows insignificant changes downstream. The arithmetic mean of chert pebbles decreases significantly only from site 3 to site 4 . (Table 2, Fig. 7). The roundness value of chert and sandstone pebbles shows insignificant changes 


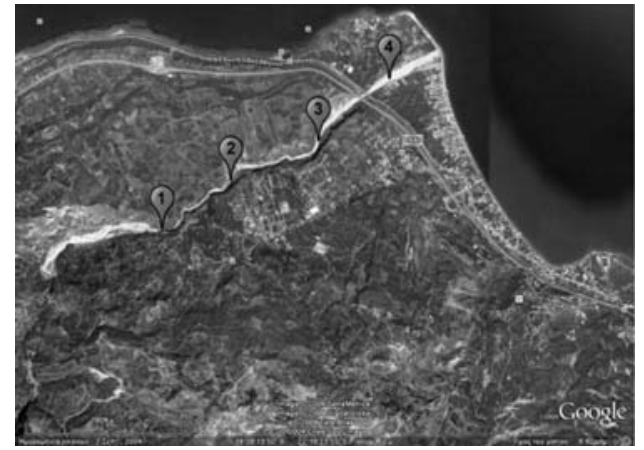

Fig. 2: Map of Krathis stream with paddles showing the sampling sites.

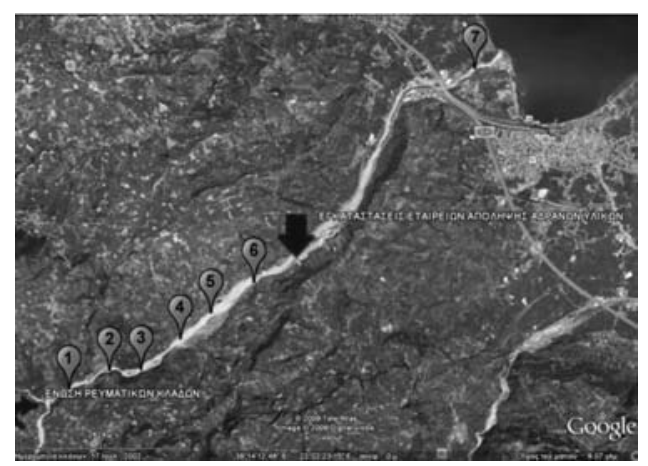

Fig. 4: Sampling map of Meganitis stream. The paddles show the sample stations. The black arrow shows a zone of aggregate quarry. The black concave arrow shows the joining of a tributary with the main channel.

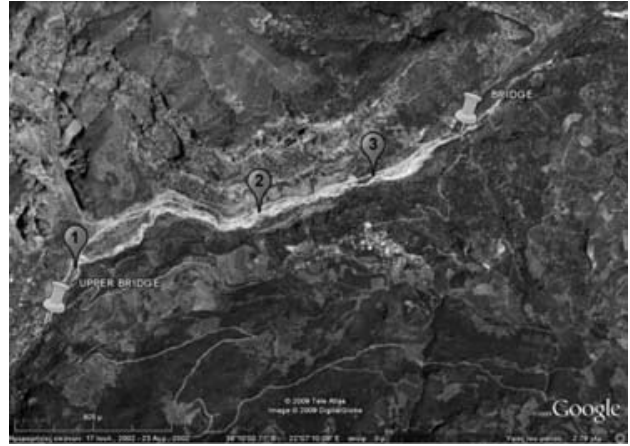

Fig. 3: Sampling map of Kerinitis stream. The paddles show the sample stations. The pushpins show two bridges respecti-vely.

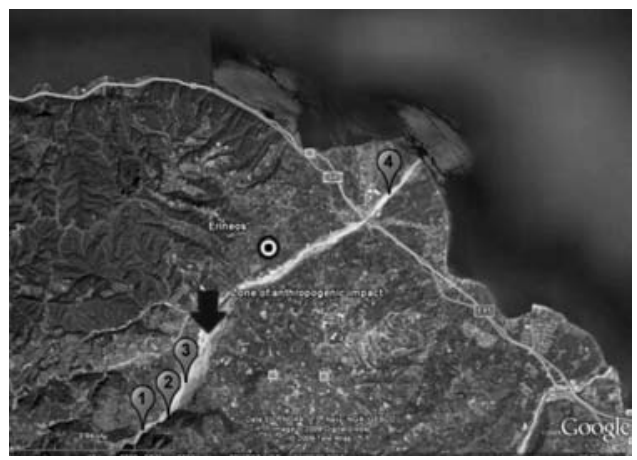

Fig. 5: Sampling map of Finikas stream. The paddles show the sample stations. The black arrow shows a zone of aggre-gate quarry.

among the sample sites. The roundness value of limestone pebbles becomes significantly better only from site 3 to site 4 . The conglomerate pebbles become significantly better from site 2 to site 3 (Table 3, Fig. 8), also.

Table 1. Percentage lithological composition of pebbles at the sample sites in the Krathis stream.

\begin{tabular}{|c|c|c|c|c|}
\hline $\begin{array}{c}\text { Krathis } \\
\text { Sample sites }\end{array}$ & $\begin{array}{c}\text { Limestone } \\
\text { grains } \\
\%\end{array}$ & Chert grains $\%$ & $\begin{array}{c}\text { Sandstone grains } \\
\%\end{array}$ & $\begin{array}{c}\text { Conglomerate } \\
\text { grains } \\
\%\end{array}$ \\
\hline$\Sigma 1$ & 73,88 & 10,45 & 8,21 & 7,46 \\
\hline$\Sigma 2$ & 75 & 12,5 & 6,73 & 5,77 \\
\hline$\Sigma 3$ & 79,56 & 12,71 & 4,42 & 3,31 \\
\hline$\Sigma 4$ & 76,37 & 11,54 & 6,6 & 5,49 \\
\hline
\end{tabular}


Table 2. The values of the arithmetic mean all lithologies at the sample si-tes in the Krathis stream.

\begin{tabular}{|c|c|c|c|c|}
\hline $\begin{array}{c}\text { Krathis } \\
\text { Sample sites }\end{array}$ & $\begin{array}{c}\text { Limestone grains } \\
\text { Arithmetic mean } \\
(\mathrm{mm})\end{array}$ & $\begin{array}{c}\text { Chert grains Arith- } \\
\text { metic mean }(\mathrm{mm})\end{array}$ & $\begin{array}{c}\text { Sandstone grains } \\
\text { Arithmetic mean } \\
(\mathrm{mm})\end{array}$ & $\begin{array}{c}\text { Conglomerate } \\
\text { grains Arithmetic } \\
\text { mean }(\mathrm{mm})\end{array}$ \\
\hline$\Sigma 1$ & 65,48 & 50,29 & 52,09 & 164,3 \\
\hline$\Sigma 2$ & 62,91 & 55,69 & 73,57 & 108,33 \\
\hline$\Sigma 3$ & 55,92 & 62,22 & 57,75 & 99,33 \\
\hline$\Sigma 4$ & 41,17 & 29,1 & 43,67 & 48,11 \\
\hline
\end{tabular}

Table 3. The roundness values of all lithologies at the sample sites in the Krathis stream.

\begin{tabular}{|c|c|c|c|c|}
\hline $\begin{array}{c}\text { Krathis } \\
\text { Sample sites }\end{array}$ & $\begin{array}{c}\text { Limestone grains } \\
\text { Roundness value }\end{array}$ & $\begin{array}{c}\text { Chert } \\
\text { grains Roundness } \\
\text { value }\end{array}$ & $\begin{array}{c}\text { Sandstones grains } \\
\text { Roundness value }\end{array}$ & $\begin{array}{c}\text { Conglome-rate } \\
\text { grains Roundness } \\
\text { value }\end{array}$ \\
\hline$\Sigma 1$ & 0,42 & 0,25 & 0,42 & 0,27 \\
\hline$\Sigma 2$ & 0,39 & 0,27 & 0,55 & 0,25 \\
\hline$\Sigma 3$ & 0,42 & 0,28 & 0,5 & 0,42 \\
\hline$\Sigma 4$ & 0,47 & 0,23 & 0,47 & 0,41 \\
\hline
\end{tabular}
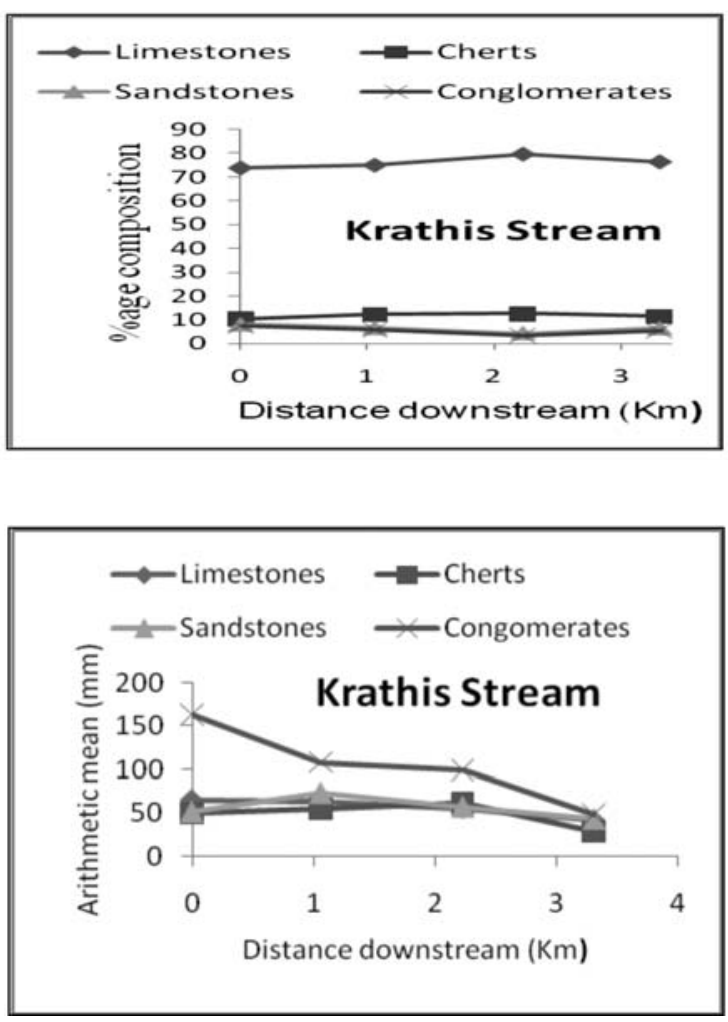

Fig. 6: Rock type vs downstream distance, Krathis stream.
Fig. 7: Downstream changes in particle size of different lithologies, Krathis Stream. 


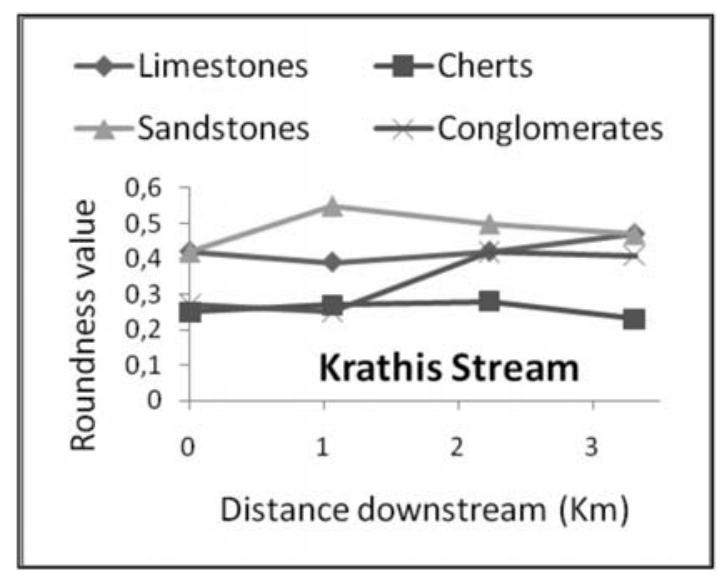

Fig. 8: Rock type roundness vs. distance downstream, Krathis Stream.

\subsection{Kerinitis Stream}

The total lithological assemblages show significant differences among the sample localities. These differentiations are the result of decrease of percentage of limestone pebbles and the increase respectively of sandstone pebbles from site 2 to site 3 (Table 4, Fig. 9). The arithmetic mean of limestone and chert pebbles is decreased significant only from site 1 to site 2 . Conversely the ari-thmetic mean of sandstone pebbles shows significant decrease downstream only from site 2 to site 3 (Table 5, Fig. 10).The roundness value of chert and sandstone pebbles shows insignificant changes among the sample sites. The roundness value of limestone pebbles becomes significant worse only between the site 1 and the site 2 and there is no significant change between the site 2 and the site 3 (Table 6, Fig. 11).

Table 4. Percentage lithological composition of pebble at the sample sites in the Kerinitis Stream.

\begin{tabular}{|c|c|c|c|}
\hline $\begin{array}{c}\text { Kerinitis } \\
\text { Sample sites }\end{array}$ & $\begin{array}{c}\text { Limestone grains } \\
\%\end{array}$ & $\begin{array}{c}\text { Chert grains } \\
\%\end{array}$ & $\begin{array}{c}\text { Sandstone grains } \\
\%\end{array}$ \\
\hline$\Sigma 1$ & 90,08 & 7,44 & 2,48 \\
\hline$\Sigma 2$ & 87,41 & 8,39 & 4,2 \\
\hline$\Sigma 3$ & 76 & 10,67 & 13,33 \\
\hline
\end{tabular}

Table 5. The values of the arithmetic mean all lithogies at the sample sites in the Kerinitis Stream.

\begin{tabular}{|c|c|c|c|}
\hline $\begin{array}{c}\text { Kerinitis } \\
\text { Sample } \\
\text { Sites }\end{array}$ & $\begin{array}{c}\text { Limestone } \\
\text { grains } \\
\text { Arithmetic } \\
\text { mean(mm) }\end{array}$ & $\begin{array}{c}\text { Chert } \\
\text { grains } \\
\text { Arithmetic } \\
\text { mean(mm) }\end{array}$ & $\begin{array}{c}\text { Sandstone } \\
\text { grains } \\
\text { Arithmetic } \\
\text { Mean(mm) }\end{array}$ \\
\hline$\Sigma 1$ & 177,83 & 111,83 & 110 \\
\hline$\Sigma 2$ & 115,66 & 47,33 & 111,67 \\
\hline$\Sigma 3$ & 99,31 & 46,25 & 54,38 \\
\hline
\end{tabular}

Table 6. The roundness values of all lithologies at the sample sites in the Kerinitis Stream.

\begin{tabular}{|c|c|c|c|}
\hline $\begin{array}{c}\text { Kerinitis } \\
\text { Sample } \\
\text { sites }\end{array}$ & $\begin{array}{c}\text { Limestone } \\
\text { grains } \\
\text { Roundness } \\
\text { value }\end{array}$ & $\begin{array}{c}\text { Chert } \\
\text { grains } \\
\text { Roundness } \\
\text { value }\end{array}$ & $\begin{array}{c}\text { Sandstone } \\
\text { grains } \\
\text { Roundness } \\
\text { value }\end{array}$ \\
\hline$\Sigma 1$ & 0,55 & 0,33 & 0,67 \\
\hline$\Sigma 2$ & 0,52 & 0,3 & 0,76 \\
\hline$\Sigma 3$ & 0,51 & 0,34 & 0,56 \\
\hline
\end{tabular}




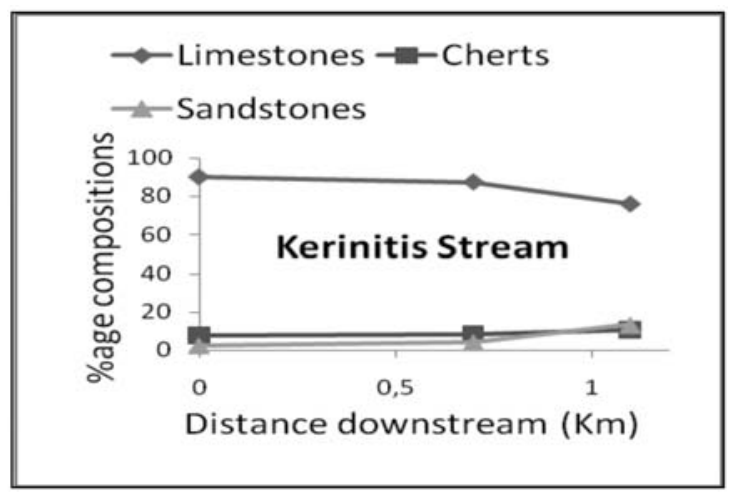

Fig. 9: Rock type vs. downstream distance, Kerinitis Stream.

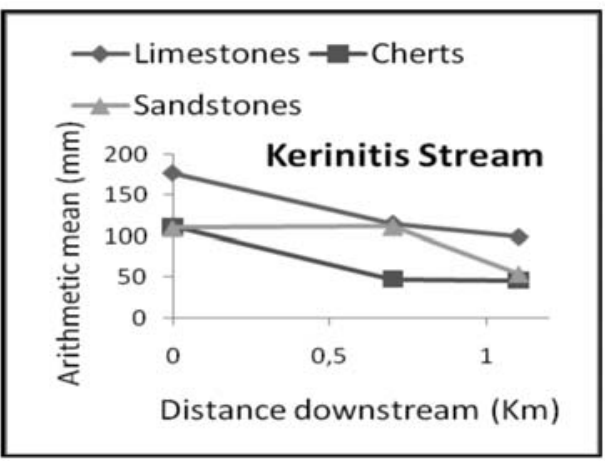

Fig. 10: Downstream changes in particle size of different lithologies, Kerinitis Stream.

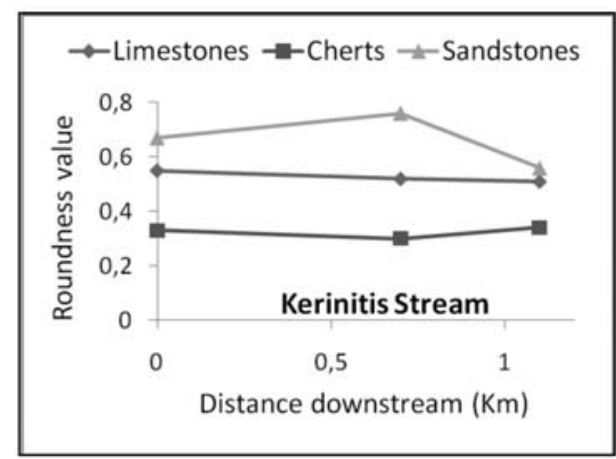

Fig. 11: Rock type roundness vs distance downstream, Kerinitis stream.

\subsection{Meganitis Stream}

The lithological assemblage shows significant differences among the sample localities (Table 7 , Fig.12). This differentiation is the result of percentage lithological changes of limestone and sandstone pebbles. The percentage of limestone grains increases from site 1 to site 2 and then gradually decreases through site 3 to the site 4 while increases again from site 6 to site 7 . The percentage of chert pebbles shows a weak decrease both from site 1 to site 2 and from site 6 to site 7 . The percentage of sandstone pebbles shows a weak decrease from site 1 to site 2 and a significant decrease from site 6 to site 7 . The arithmetic mean of limestones shows significant decrease in both from site 1 to site 2 and from site 6 to site 7 . The arithmetic mean of chert pebbles does not show changes downstream. The arithmetic mean of sandstones pebbles shows significant decrease from site 5 to site 6 and then is increased significant from site 6 to site 7(Table 8, Fig. 13). The roundness value of limestone pebbles shows a discontinuous reduction from site 1 to site 6 and then becomes significantly better from site 6 to site 7 . The roundness value of chert pebbles shows significant decrease from site 2 to site 3 and then remains constant up to the site 6 . This value becomes significantly better from site 6 to site 7. The roundness value of sandstone pebbles shows insignificant changes from site 4 to site 7 . This becomes significantly better at site 2 in relation to the other sites except the sites 3 and 1 . The roundness value at site 3 shows that is better in relationship to that of side 6 (Table 9, Fig. 14). 
Table 7. Percentage lithological composition of pebbles at the sample sites in the Meganitis stream.

\begin{tabular}{|c|c|c|c|}
\hline $\begin{array}{c}\text { Meganitis } \\
\text { Sample } \\
\text { sites }\end{array}$ & $\begin{array}{c}\text { Limestone } \\
\text { grains } \\
\%\end{array}$ & $\begin{array}{c}\text { Chert grains } \\
\%\end{array}$ & $\begin{array}{c}\text { Sandstone } \\
\text { grains } \\
\%\end{array}$ \\
\hline$\Sigma 1$ & 63,64 & 11,57 & 24,79 \\
\hline$\Sigma 2$ & 68,26 & 9,58 & 22,16 \\
\hline$\Sigma 3$ & 68,58 & 8,05 & 23,37 \\
\hline$\Sigma 4$ & 62,89 & 12,22 & 24,89 \\
\hline$\Sigma 5$ & 61,21 & 14,23 & 24,56 \\
\hline$\Sigma 6$ & 61,69 & 11,44 & 26,87 \\
\hline$\Sigma 7$ & 77,87 & 8,3 & 13,83 \\
\hline & & & \\
\hline
\end{tabular}

Table 9. The roundness values of all lithologies at the sample sites in the Meganitis stream.

\begin{tabular}{|c|c|c|c|}
\hline $\begin{array}{c}\text { Meganitis } \\
\text { Sample } \\
\text { sites }\end{array}$ & $\begin{array}{c}\text { Limestone } \\
\text { grains } \\
\text { Roundness } \\
\text { value }\end{array}$ & $\begin{array}{c}\text { Chert } \\
\text { grains } \\
\text { Roundness } \\
\text { value }\end{array}$ & $\begin{array}{c}\text { Sandstone } \\
\text { grains } \\
\text { Roundness } \\
\text { value }\end{array}$ \\
\hline$\Sigma 1$ & 0,46 & 0,45 & 0,56 \\
\hline$\Sigma 2$ & 0,43 & 0,43 & 0,66 \\
\hline$\Sigma 3$ & 0,42 & 0,26 & 0,58 \\
\hline$\Sigma 4$ & 0,39 & 0,22 & 0,51 \\
\hline$\Sigma 5$ & 0,38 & 0,2 & 0,51 \\
\hline$\Sigma 6$ & 0,36 & 0,23 & 0,44 \\
\hline$\Sigma 7$ & 0,49 & 0,51 & 0,51 \\
\hline
\end{tabular}

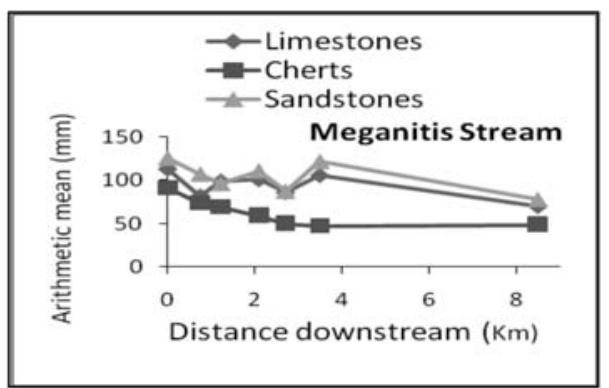

Fig. 13: Downstream changes in particle size of different lithologies, Meganitis stream.
Table 8. The values of the arithmetic mean all lithogies at the sample sites in the Meganitis stream.

\begin{tabular}{|c|c|c|c|}
\hline $\begin{array}{c}\text { Meganitis } \\
\text { Sample } \\
\text { sites }\end{array}$ & $\begin{array}{c}\text { Limestone } \\
\text { grains } \\
\text { Arithmetic } \\
\text { mean }\end{array}$ & $\begin{array}{c}\text { Chert } \\
\text { grains } \\
\text { Arithmetic } \\
\text { mean }\end{array}$ & $\begin{array}{c}\text { Sandstone } \\
\text { grains } \\
\text { Arithmetic } \\
\text { mean }\end{array}$ \\
\hline$\Sigma 1$ & 112,79 & 91,07 & 125,7 \\
\hline$\Sigma 2$ & 81,75 & 73,94 & 107,16 \\
\hline$\Sigma 3$ & 99,02 & 69,29 & 96,08 \\
\hline$\Sigma 4$ & 100,67 & 59,3 & 110,95 \\
\hline$\Sigma 5$ & 85,79 & 50,11 & 87,17 \\
\hline$\Sigma 6$ & 105,51 & 47,41 & 121,66 \\
\hline$\Sigma 7$ & 69,84 & 48,71 & 77,66 \\
\hline
\end{tabular}

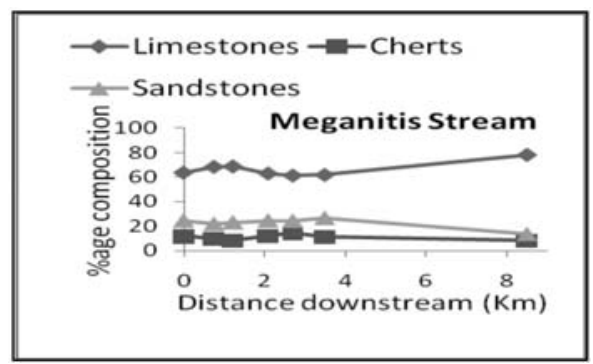

Fig. 12: Rock type vs downstream distance, Meganitis stream.

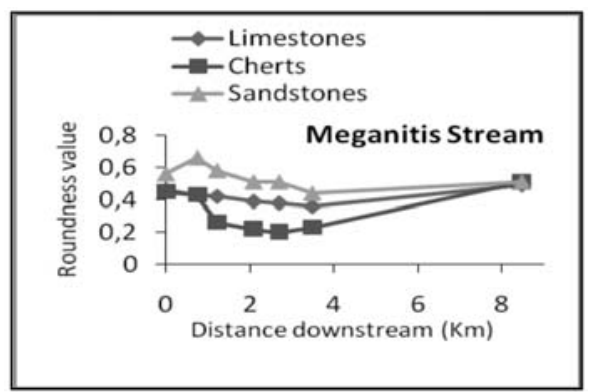

Fig. 14: Rock type roundness vs distance downstream, Meganitis stream. 


\subsection{Finikas Stream}

The composition of lithological assemblage shows insignificant differences among the three first sample localities (Table 10, Fig.15). In the fourth sample site in relation to the other three sites, the percentage of limestone pebbles increases significant while the percentage of the other two lithologies is decreased significant. The arithmetic mean of limestone pebbles shows significant decrease downstream from site 2 to site 4 while there is no change from site 1 to site 2 . The arithmetic mean of chert pebbles does not show significant change from the site 1 to site 3 while is decreased from site 3 to site 4 . The arithmetic mean of sandstone pebbles does not show significant change from site 1 to site 3 while is decreased from site 3 to site 4 (Table 11, Fig. 16). The roundness value of limestone pebbles increases significant from site 1 to site 4 through the sites 3 and 4 . The roundness value of chert and sandstone pebbles does not show significant change from site 1 to site 3 while increases significant from site 3 to site 4 (Table 12, Fig. 17).

Table 10. Percentage lithological composition of pebbles at the sample sites in the Finikas stream.

\begin{tabular}{|c|c|c|c|}
\hline $\begin{array}{c}\text { Finikas } \\
\text { stream } \\
\text { Sample } \\
\text { sites }\end{array}$ & $\begin{array}{c}\text { Limestone } \\
\text { grains } \\
\%\end{array}$ & $\begin{array}{c}\text { Chert } \\
\text { grains } \%\end{array}$ & $\begin{array}{c}\text { Sandstone } \\
\text { grains } \\
\%\end{array}$ \\
\hline$\Sigma 1$ & 67,2 & 14,29 & 18,52 \\
\hline$\Sigma 2$ & 60,74 & 18,02 & 21,23 \\
\hline$\Sigma 3$ & 65,23 & 15,22 & 19,54 \\
\hline$\Sigma 4$ & 81,85 & 11,08 & 7,08 \\
\hline
\end{tabular}

Table 12. The roundness values of all lithologies at the sample sites in the Finikas stream.

\begin{tabular}{|c|c|c|c|}
\hline $\begin{array}{c}\text { Finikas } \\
\text { Stream } \\
\text { Sample } \\
\text { sites }\end{array}$ & $\begin{array}{c}\text { Limestone } \\
\text { grains } \\
\text { Roundness } \\
\text { value }\end{array}$ & $\begin{array}{c}\text { Chert } \\
\text { grains } \\
\text { Roundness } \\
\text { value }\end{array}$ & $\begin{array}{c}\text { Sandstones } \\
\text { grains } \\
\text { Roundness } \\
\text { value }\end{array}$ \\
\hline$\Sigma 1$ & 0,38 & 0,22 & 0,51 \\
\hline$\Sigma 2$ & 0,45 & 0,24 & 0,54 \\
\hline$\Sigma 3$ & 0,45 & 0,23 & 0,56 \\
\hline$\Sigma 4$ & 0,52 & 0,31 & 0,75 \\
\hline
\end{tabular}

Table 11. The values of the arithmetic mean all lithologies at the sample sites in the Finikas stream.

\begin{tabular}{|c|c|c|c|}
\hline $\begin{array}{c}\text { Finikas } \\
\text { stream } \\
\text { Sample } \\
\text { sites }\end{array}$ & $\begin{array}{c}\text { Limestone } \\
\text { grains Arith- } \\
\text { metic } \\
\text { mean(mm) }\end{array}$ & $\begin{array}{c}\text { Chert grains } \\
\text { Arithmetic } \\
\text { mean(mm) }\end{array}$ & $\begin{array}{c}\text { Sandstone } \\
\text { grains } \\
\text { Arithmetic } \\
\text { mean(mm) }\end{array}$ \\
\hline$\Sigma 1$ & 157,94 & 94,56 & 142,07 \\
\hline$\Sigma 2$ & 162,73 & 96,04 & 154,7 \\
\hline$\Sigma 3$ & 135,15 & 122,51 & 165,78 \\
\hline$\Sigma 4$ & 72,58 & 58,53 & 60,09 \\
\hline
\end{tabular}

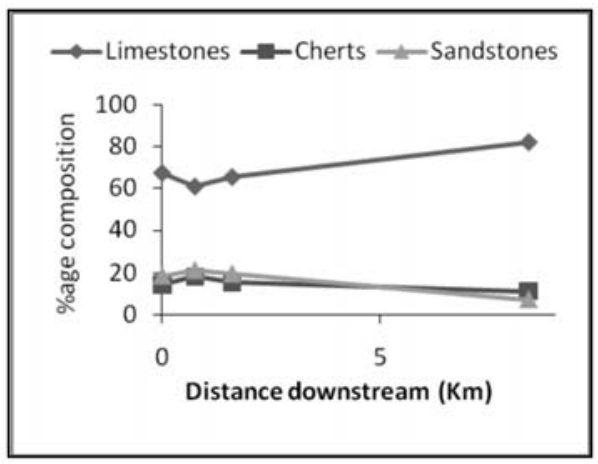

Fig. 15: Rock type vs distance downstream, Finikas stream. 


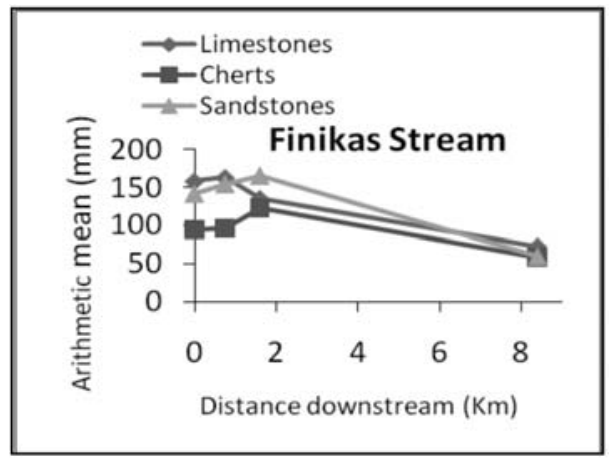

Fig. 16: Downstream changes in particle size of different lithologies, Finikas stream.

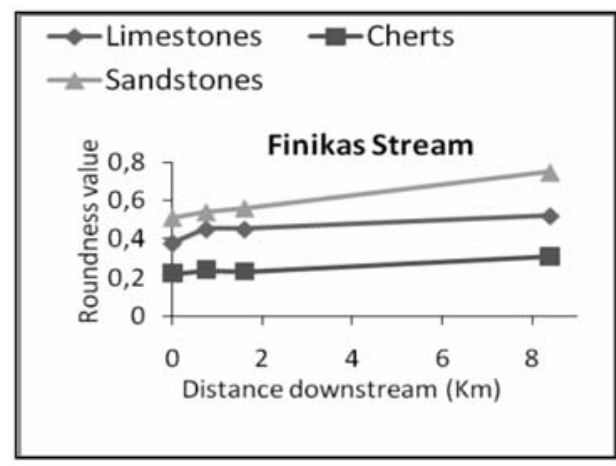

Fig. 17: Rock type roundness vs distance downstream, Finikas stream.

\section{Conclusions-Discussion}

There is absence of variability in lithologic content from one sample site to other, in the Krathis stream. This effect is due to the small total distance of sampling. The reduction of soft rock types as the limestone and sandstone pebbles by the abrasion and breakage is negligible in a short distance of stream transport. The arithmetic mean of the limestone pebbles is decreased from site 2 up to the site 4 while the arithmetic mean of the chert pebbles is decreased from site 3 up to the site 4 . The arithmetic mean of sandstone and conglomerate pebbles does not change along the distance of sampling. The stream channel from site 2 up to the site 4 is wide while from site 1 up to the site 2 is very narrow (Fig. 2). The stream width appears to assert a local control on grain size; coarse particles are associated with narrow channel reaches, whereas smaller particles are associated with wide channel reaches (Rengers \& Wohl, 2006). Wide sections, therefore, display downstream fining of sediment and can be explain the downstream fining of limestone and chert pebbles because of the selective transport. The roundness value of chert and sandstone pebbles does not change along the distance of sampling. In contrary, the roundness value of limestone pebbles increases from site 3 up to the site 4 while the roundness value of conglomerate pebbles also increases from site 2 up to the site 3 . The increase of roundness downstream is due to the previously mentioned selective transport.

There is variability in the lithologic content in short distance of sampling, in the Kerinitis stream. The Chert ratio curves show irregularities which means that the proportion of chert does not increase with distance at the expense of all other rock types (Fig. 18). This is due partly to local sample variation, partly to influx of new material, and partly to effects of increase or decrease of other types, (Plumley, 1948). These three reasons justify the variability. The arithmetic mean either remains stable or is decreased between two successive sampling positions. This behaviour of the arithmetic means is due to the contamination by tributary stream between the site 1 and the site 2 and the sort distance of sampling. The roundness values of chert and sandstone pebbles remain unchanged along the distance of sampling. The roundness value of limestone pebbles shows a decrease from site 1 up to the site 2 and it remains stable from site 2 up to the site 3 . The decrease in roundness with distance of transport is impossible unless if contamination or short travel of gravels exist along the distance of sampling. These facts happen as previously mentioned.

The lithologic content shows a variation along the distance of sampling, in the Meganitis stream. 


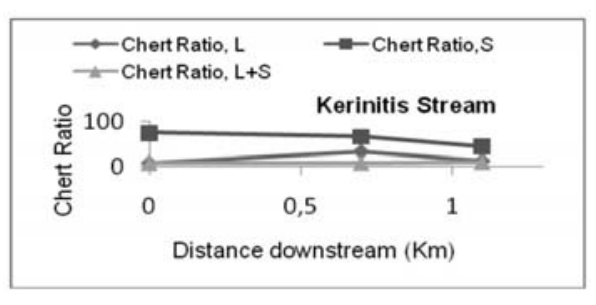

Fig. 18: Ratio of Chert to Chert plus each component: $\mathrm{L}$, Limestone; S, Sandstone; L+S, Limestone plus Sandstone.

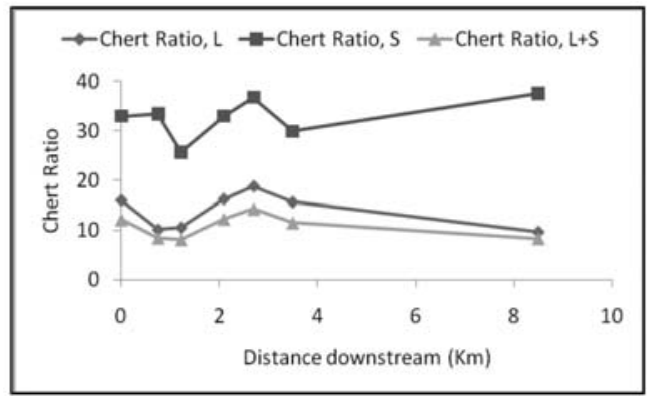

Fig. 19: Ratio of Chert to Chert plus each component: L, Limestone; S, Sandstone; L+S, Limestone plus Sandstone.

The Chert ratio curves show the absence of any action of the abrasion, breakage and weathering. (Fig. 19).

However, this lack of action is misleading. The contamination with new material among the sample stations and the anthropogenic impact obscure the operation of the abrasion, breakage and weathering. This contamination and gravel mining determine the lithologic variability (Fig. 4). Also, the selective transport and abrasion is obscured by contamination of new material and gravel mining. So, a downstream fining trend is not observed. The roundness fluctuates or remains constant. This absence of any systematic change is owed to the same reasons which interpret the lithological variability.

The lithologic content remains constant in the first three localities of sampling of Finikas stream while it changes from the third up to fourth station of sampling. The lack change in the lithological content along the first three sampling stations is interpreted by the small distance between them. The change in the lithological content from the third up to the fourth station of sampling is explained by the presence of aggregate quarry between them (Fig. 5). The arithmetic mean of limestone pebbles shows a downstream fining trend from site 2 up to the site 4 and remains constant from site 1 up to the site 2 . The arithmetic mean of chert and sandstone pebbles remains constant from site 1 up to the site 3 and shows a decrease from site 3 up to the site 4 . The previous mentioned changes of arithmetic mean of the three lithologies are due to the pebble mining. The roundness value of limestone pebbles increases from site 1 up to the site 4 through sites 2 and 3 . In contrary, the roundness value of chert and sandstone pebbles remains constant from site 1 up to the site 3 and increases only from site 3 up to the site 4. The roundness value trend of limestone pebbles could be the result of the selective transport. However, we must assume that the chert and sandstone pebbles show the same roundness trend as limestone pebbles. However this is not in effect. So, the gravel mining regulates the roundness behavior along the distance of sampling.

\section{References}

Bunte, K.,Abt, S.R., 2001. Sampling surface and subsurface particle-size distributions in Wadable gravel and cobble-bed streams for analysis in sediment transport, Hydraulics, and stream-bed monitoring, 
pp.144-166.

Kontopoulos, N., Panagos, A., 1979. Morphometrical Analysis of pebbles from the Evinos River, Western Greece. Bull. Geol. Soc. Greece XIV/1, pp.23-50.

Karkanas, A., Kontopoulos, N., 2004. Grain size and morphometrical characteristics of Boeotian Kifisos stream gravel-bed and their geological importance. Proceedings of the $10^{\text {th }}$ International Congress, Thessaloniki. Bull. Geol. Soc. Greece XXXVI/2, pp. 660-669.

Krumbein, N., 1942. The effects of abrasion on the size, shape and roundness of rock fragments. Journal of Geology 49, pp.482-520.

Pettijohn, J. F., 1975. Sedimentary rocks, 3nd ed.: New York, Harper \& Row, 628p.

Plumley, W.J., 1948.The Black Hills Terrace gravels: a study of sediment transport. Journal of Geology 56, pp. 526-577.

Rengers, F., Wohl, E., 2007. Trends of grain sizes on gravel bars in the Rio Charges, Panama Geomorphology 83, pp. 282-293. 